\title{
Comparison of immune reconstitution between anti-T-lymphocyte globulin and posttransplant cyclophosphamide as acute graft-versus-host disease prophylaxis in allogeneic myeloablative peripheral blood stem cell transplantation
}

\author{
Radwan Massoud, Nico Gagelmann, Ulrike Fritzsche-Friedland, Gaby Zeck, \\ Silke Heidenreich, Christine Wolschke, Francis Ayuk, Maximilian Christopeit \\ and Nicolaus Kröger
}

Department of Stem Cell Transplantation, University Medical Center HamburgEppendorf, Hamburg, Germany

\section{ABSTRACT}

\begin{abstract}
A nti-T-cell lymphocyte globulin (ATLG) and posttransplant cyclophosphamide (PTCy) are now widely used strategies to prevent graft-versus-host disease (GVHD) after allogeneic stem cell transplantation. Data comparing immune reconstitution (IR) between ATLG and PTCy is scarce. This retrospective study conducted at the University Medical Center Hamburg-Eppendorf (UKE) compares PTCy $(n=123)$ and ATLG $(n=476)$ after myeloablative allogeneic peripheral blood stem cell transplant. Detailed phenotypes of T, B natural killer (NK), natural killer T (NKT) cells were analyzed by multicolor flow at day 30, 100 and 180 posttransplant. Incidence of infections, viral reactivations, GVHD and relapse were collected. Neutrophil engraftment was significantly delayed in the PTCy group (median day 12 vs. day 10, $P<0.001$ ) with a high incidence of infection before day+100 in the PTCy arm but a higher Epstein-Barr virus reactivation in the ATLG arm and comparable cytomegalovirus reactivation. Overall incidence of acute GVHD was similar but moderate/severe chronic GVHD was seen more often after PTCy $(44 \%$ vs. $38 \%, P=0.005)$. ATLG resulted in a faster reconstitution of CD8+ T, NK, NKT and $\gamma \delta \mathrm{T}$ cells while CD4 T cells and B cells reconstituted faster after PTCy. Similar reconstitution was observed for T-regulatory cells and B cells. Non-relapse mortality relapse incidence, disease-free survival, and overall survival did not differ significantly between both arms. Even though differences in IR were related to a decreased incidence of infection and moderate/severe cGVHD in the ATLG group they had no impact on any of the other long-term outcomes. However, it remains undetermined which regimen is better as GVHD prophylaxis.
\end{abstract}

\section{Introduction}

Allogeneic stem cell transplantation (allo-SCT) is a potentially curative treatment strategy for hematological diseases. ${ }^{1}$ This is attributed mainly to the graftversus-tumor effect derived from transferring the donor's immune system to the recipient. ${ }^{2}$ However, the benefit of allo-SCT may be offset by increased transplantrelated mortality (TRM) especially due to graft- versus-host disease (GVHD). ${ }^{3}$ In an attempt to decrease the incidence of GVHD physicians employ a multitude of strategies, including in vivo T-cell depletion (TCD) with pretransplant anti-T-lymphocyte globulin (ATLG) ${ }^{4,5}$ and/or posttransplant cyclophosphamide (PTCy). ${ }^{6-8}$

GVHD prophylaxis with PTCy decreases the incidence of graft rejection and GVHD by impairing the function of alloreactive T cells. ${ }^{9}$ However, data is scarce on the effect of PTCy effect on immune reconstitution (IR) post-allo-SCT, especially when compared to the standard use of ATLG as a TCD tool. ${ }^{4,5,10,11}$ In this
Ferrata Storti Foundation

Haematologica 2022

Volume 107(4):857-867

Correspondence:

NICOLAUS KRÖGER

nkroeger@uke.uni-hamburg.de

Received: September 10, 2020.

Accepted: March 31, 2021.

Pre-published: April 8, 2021.

https://doi.org/10.3324/haematol.2020.271445

(C)2022 Ferrata Storti Foundation

Material published in Haematologica is covered by copyright. All rights are reserved to the Ferrata Storti Foundation. Use of published material is allowed under the following terms and conditions:

https://creativecommons.org/licenses/by-nc/4.0/legalcode. Copies of published material are allowed for personal or internal use. Sharing published material for non-commercial purposes is subject to the following conditions:

https://creativecommons.org/licenses/by-nc/4.0/legalcode, sect. 3. Reproducing and sharing published material for commercial purposes is not allowed without permission in writing from the publisher. 
study we aim to compare the IR kinetics and transplant outcomes between ATLG and PTCy as TCD strategies in patients undergoing allo-SCT with myeloablative conditioning (MAC) and peripheral blood stem cells (PBSC).

\section{Methods}

This retrospective study conducted at the University Medical Center Hamburg-Eppendorf (UKE) with a primary outcome to compare IR between PTCy versus ATLG in vivo TCD in adult patients who received MAC PBSC allo-SCT. Secondary outcomes included incidence of viral reactivations, engraftment, infections, acute GVHD (aGHVD), chronic GVHD (cGVHD), non-relapse mortality (NRM), progression-free survival (PFS), overall survival (OS). All patients signed written informed consents for treatment, and the study was approved by the Institutional Review Board of UKE.

$M A C$ regimens were defined according to working group definition. ${ }^{12}$ ATLG (Grafalon ${ }^{\circledR}$, Neovii, Switzerland) was given at a dose of $30 \mathrm{mg} / \mathrm{kg}$ for related donor or $60 \mathrm{mg} / \mathrm{kg}$ for unrelated donor with a trend in recent years to give the lower dose for both groups. All ATLG doses were fractionated between days 4 to -1 . PTCy was administered as $50 \mathrm{mg} / \mathrm{kg} /$ day. Posttransplant immunosuppression was given on days +3 and +4 combined with calcineurin inhibitor (tacrolimus for unrelated donor or haplo-identical donor, and cyclosporine for related donor) and mycophenolate mofetil for mismatched transplants. Similar supportive care was used for all patients per institutional guidelines including antimicrobial prophylaxis consisting of fluoroquinelone for bacterial infections, trimethorpin-sulfamethoxazole or pentamidine for Pnemocystis jiroveci, micafungin for fungal infections and acyclovir for viral infections. Patients were screened weekly for cytomegalovirus (CMV) and Epstein-Barr virus (EBV) by blood polymerase chain reaction (PCR).

Neutrophil engraftment was defined as the first 3 consecutive days with a measure of an absolute neutrophil count $>0.5 \times 10^{9} / \mathrm{L}$. Platelet engraftment was defined as the first consecutive days with a platelet count $>20 \times 10^{9} / \mathrm{L}$ without transfusion support.

Acute GVHD was graded according to standard criteria. ${ }^{13}$ Chronic GVHD was graded according to National Institute of Health (NIH) criteria routinely at every visit after transplantation. ${ }^{14}$

\section{Infections were defined as any microbial testing with a positive result and requiring therapy.}

As per institution guidelines, blood samples were collected for each patient on days 30,100 and 180 post-allo-SCT. Samples were used directly after red blood cell lysis following 10 minutes of incubation with erythrocyte lysing reagent without fixative. Immunophenotypes were assessed using four color cytometry using mouse anti-human antibodies for the following cells: $\mathrm{T}$ lymphocytes (CD3+), activated $\mathrm{T}$ lymphocytes (CD3+HLADR+), T-helper cells (CD3+/CD4+), cytotoxic T cells (CD3+/CD8+), B lymphocytes (CD19+), B-lymphocyte subpopulations (CD19+CD5+CD1d+)(CD19+CD27+), naïve B cells (CD19+CD27-CD10+), natural killer (NK) cells (CD56+CD3-), natural killer $\mathrm{T}(\mathrm{NKT})$ cells $(\mathrm{CD} 56+\mathrm{CD} 3+)$, naïve T-helper cells (CD4+CD45RA+), memory T-helper cells (CD4+CD45R0+), naive cytotoxic $\mathrm{T}$ cells (CD8+CD45RA+), memory cytotoxic $\mathrm{T}$ cells $(\mathrm{CD} 8+\mathrm{CD} 45 \mathrm{R} 0+), \gamma \delta \mathrm{T}$ cells $(\gamma \delta \mathrm{TCR}+, \mathrm{CD} 3+)$, regulatory $\mathrm{T}$ cells (CD4+CD25+CD127low-neg).

\section{Statistical analyses}

All data was retrospectively collected, and was summarized by standard descriptive statistical methods. $\chi^{2}$ test was used to compare categorical variables, whereas continuous variables were compared using Student's $t$-test. We defined disease-free survival (DFS) as survival without relapse or progression of hematological disease; we censored patients without disease or progression at the time of the last follow-up. We defined OS and NRM as death from any cause, and without evidence of relapse respectively. We used the Kaplan-Meier method to calculate the probabilities of moderate/severe cGVHD relapse-free survival, DFS and OS; and the cumulative incidence functions were used to estimate RI and NRM in a competing risk setting. All analysis was performed using SPSS version 26.0 and ACCorD.

\section{Results}

\section{Patients and transplant characteristics}

In order to have comparable groups we selected only patients receiving myeloablative conditioning for their first allo-SCT with only PBSC as a stem cell source. From 2005 to 2019, 599 patients were included in the study. Four hundred and seventy-six patients received ATLG, with $34 \%$ and $66 \%$ receiving $30 \mathrm{mg} / \mathrm{kg}$ and $60 \mathrm{mg} / \mathrm{kg}$ ATLG respectively. One hundred and twenty-three patients received PTCy. The median age at transplant was 53 years (range, $18-75$ years) in both groups. Seventy nine percent and $72 \%$ were transplanted from a full match donor (HLA10/10) in the ATLG and PTCy group, respectively. All patients, donor and transplant characteristics are listed in Table 1.

\section{Transplant outcomes}

All transplant outcomes are summarized in Table 2.

\section{Engraftment}

Platelet and neutrophil engraftment were significantly delayed in the PTCy group when compared to the ATLG group; with a median of 12 days (range, 8-36 days) to neutrophil in the ATLG versus 16 days (range, 12-27 days) in PTCy group $(P<0.001)$; and a median of 15 days (range, 8-99 days) to platelet engraftment in the ATLG versus 21 days (range, 9-99 days) in the PTCy group $(P=0.024)$.

\section{Cytomegalovirus infections and Epstein-Barr virus reactivation}

We observed no significant differences in incidence of CMV reactivation before day 100 (ATLG 46\%, PTCy $50 \%$ ). The overall incidence of infection before day 100 was significantly higher in the PTCy group (91\%) when compared to the ATLG group $(75 \%), P<0.001$. The incidence of EBV reactivation before days 100 in the ATLG group was higher than the PTCy group (33\% vs. 16\%, $P<0.001)$.

\section{Graft-versus-host disease}

The cumulative incidences of aGVHD grade 2-4 and 34 were similar between the two groups with $36 \%$ and $15 \%$ in the ATLG group and $40 \%$ and $12 \%$ in the PTCy group.

The cumulative incidence of all grade cGVHD were similar between the two groups, $15 \%$ and $27 \%$ in the ATLG and PTCy groups respectively, however we observed a higher cumulative incidence of moderate and severe cGVHD in the PTCy group, 38\% ATLG versus $44 \%$ PTCy $(P=0.005)$. 
Table1. Patients and transplant characteristics.

\begin{tabular}{|c|c|c|c|}
\hline Patients & $\begin{array}{l}\text { ATLG } \\
N(\%)\end{array}$ & $\begin{array}{l}\text { PTCy } \\
\mathrm{N}(\%)\end{array}$ & $P$ \\
\hline Total patients & $476(100)$ & $123(100)$ & \\
\hline $\begin{array}{l}\text { ATLG dose } \\
30 \mathrm{mg} / \mathrm{kg} \\
60 \mathrm{mg} / \mathrm{kg}\end{array}$ & $\begin{array}{l}162(34) \\
314(66)\end{array}$ & & \\
\hline Mean age (Standard Deviation) & $50(14)$ & $50(13)$ & NS \\
\hline $\begin{array}{l}\text { Disease } \\
\text { ALL } \\
\text { AML } \\
\text { CML } \\
\text { MDS } \\
\text { MDS-MPN } \\
\text { HL } \\
\text { NHL } \\
\text { MM } \\
\text { PMF } \\
\text { Other AL }\end{array}$ & $\begin{array}{c}27(10) \\
206(43) \\
16(3) \\
43(9) \\
6(1) \\
4(1) \\
75(16) \\
64(13) \\
12(3) \\
3(1)\end{array}$ & $\begin{array}{c}35(29) \\
23(19) \\
1(1) \\
2(2) \\
4(3) \\
2(2) \\
13(11) \\
38(31) \\
2(2) \\
3(2)\end{array}$ & $<0.001$ \\
\hline $\begin{array}{c}\text { ECOG } \\
0 \\
1 \\
2 \\
3\end{array}$ & $\begin{array}{c}115(30) \\
241(63) \\
23(6) \\
3(1)\end{array}$ & $\begin{array}{l}23(20) \\
81(72) \\
9(8) \\
0(0)\end{array}$ & NS \\
\hline Mean KI at SCT (Standard Deviation & n) $86(12)$ & $83(11)$ & 0.011 \\
\hline Mean donor age (Standard Deviatio & on) 36 (12) & $37(14)$ & NS \\
\hline $\begin{array}{l}\text { Donor/ recipient CMV serology } \\
\text { D-/R- } \\
\text { D+/R+ } \\
\text { D-/R+ } \\
\text { D+/R- }\end{array}$ & $\begin{array}{l}151(32) \\
194(41) \\
62(13) \\
68(14)\end{array}$ & $\begin{array}{l}41(34) \\
58(47) \\
9(7) \\
15(12)\end{array}$ & NS \\
\hline $\begin{array}{l}\text { Donor-Recipient sex } \\
\text { No mismatch } \\
\text { Male-Male } \\
\text { Female-Female } \\
\text { Mismatch } \\
\text { Male - Female } \\
\text { Female - Male }\end{array}$ & $\begin{array}{l}322(67) \\
241(51) \\
81(17) \\
154(32) \\
101(21) \\
53(11)\end{array}$ & $\begin{array}{l}75(61) \\
59(48) \\
16(13) \\
48(39) \\
32(26) \\
16(13)\end{array}$ & NS \\
\hline $\begin{array}{l}\text { ABO incompatibility } \\
\text { Isogroup } \\
\text { Minor } \\
\text { Major } \\
\text { Bidirectional }\end{array}$ & $\begin{array}{l}182(39) \\
127(27) \\
111(24) \\
48(10)\end{array}$ & $\begin{array}{c}57(47) \\
23(19) \\
33(27) \\
8(7)\end{array}$ & NS \\
\hline Median year of transplant (range) & $\begin{array}{c}2013 \\
(2005-2019)\end{array}$ & $\begin{array}{c}2015 \\
(2005-2019)\end{array}$ & $<0.001$ \\
\hline $\begin{array}{l}\text { Type of transplant } \\
\text { Related } \\
\text { Unrelated } \\
\text { Full match }(\mathrm{HLA10/10)} \\
\text { Mismatch }(\mathrm{HLA}<10 / 10) \\
\text { MRD } \\
\text { MMRD } \\
\text { MUD } \\
\text { MMUD }\end{array}$ & $\begin{array}{l}77(16) \\
399(84) \\
377(79) \\
99(21) \\
74(16) \\
3(1) \\
303(64) \\
96(20)\end{array}$ & $\begin{array}{l}45(37) \\
78(63) \\
88(72) \\
35(29) \\
31(25) \\
14(11) \\
57(46) \\
21(17)\end{array}$ & $\begin{array}{l}<0.001 \\
\\
\mathrm{NS} \\
\mathrm{NS} \\
<0.001\end{array}$ \\
\hline Mean CD34 x106/kg (SD) infused & $11.55(64)$ & $7.18(2)$ & NS \\
\hline $\begin{array}{l}\text { Conditioning details } \\
\text { Busulfan based } \\
\text { TBI based } \\
\text { Other }\end{array}$ & $\begin{array}{l}256(54) \\
130(27) \\
90(19)\end{array}$ & $\begin{array}{l}29(24) \\
55(45) \\
39(32)\end{array}$ & $<0.001$ \\
\hline $\begin{array}{l}\text { TBI } \\
\text { TBI dose } \\
\quad \leq 10 \mathrm{~Gy} \\
>10 \mathrm{~Gy}\end{array}$ & $\begin{array}{c}146(31) \\
44(9) \\
102(21)\end{array}$ & $\begin{array}{l}21(17) \\
34(28)\end{array}$ & $\begin{array}{c}0.001 \\
\text { NS }\end{array}$ \\
\hline
\end{tabular}

Immune suppression

$\begin{array}{lcc}\text { CNI+MMF } & 413(87) & 77(62) \\ \text { CNI+MTX } & 57(12) & 0(0) \\ \text { CNI } & 1(0.2) & 23(19)\end{array}$

$5(1)$

ATLG: anti T-cell lymphocyte globulin; PTCy: and post-transplant cyclophosphamide; NS: statistically not significant; ALL: acute lymphoblastic leukemia; AML: acute myeloid leukemia; CML: chronid myeloid leukemia; MDS: myelodysplastic syndrome MDS-MPN: myelodysplastic syndrome - myeloproliferative neoplasm; HL: Hodgkin lymphoma; NHL: non Hodgkin lymphoma; MM: multiple myeloma; PMF: primary myelofibrosis; Other AL: other acute leukemia; ECOG: Eastern Cooperative Oncology Group performance status; KI: Karnofsy index: CMV: cytomegalovirus; D-: donor with negative CMV serology: D+: donor with positive CMV serology: R-: recipient with negative CMV serology; R+: recipient with positive CMV serology; MRD: matched related door; MMRD: mismatched related donor; MUD: matched unrelated donor; MMUD: mismatched unrelated donor; SD: standard deviation; TBI: total body irradiation; $\mathrm{CNI}$ : calcineurin inhibitor; MMF: mycophenolate mofetil; age in years.

Table 2. Transplant outcomes.

\begin{tabular}{|c|c|c|c|}
\hline Transplant outcomes & $\begin{array}{l}\text { ATLG } \\
N(\%)\end{array}$ & $\begin{array}{l}\text { PTCy } \\
\text { N(\%) }\end{array}$ & $P$ \\
\hline Patients & $476(100)$ & $123(100)$ & \\
\hline $\begin{array}{l}\text { Leukocytes engraftment } \\
\text { median days (range) }\end{array}$ & $12(8-36)$ & $16(12-27)$ & $<0.001$ \\
\hline $\begin{array}{l}\text { Platelet engraftment median } \\
\text { days (range) }\end{array}$ & $15(8-99)$ & $21(9-99)$ & 0.024 \\
\hline $\begin{array}{l}\text { CMV reactivation [15 in ATLG, } 54 \\
\text { in PTCy missing] }\end{array}$ & $214(46)$ & $60(50)$ & NS \\
\hline $\begin{array}{l}\text { EBV reactivation [34 in ATG } \\
\text { missing, } 4 \text { in PTCy missing] }\end{array}$ & $131(33)$ & $19(16)$ & $<0.001$ \\
\hline $\begin{array}{l}\text { Overall incidence of infection } \\
\text { by day } 100\end{array}$ & $344(75)$ & $109(91)$ & $<0.001$ \\
\hline NRM at 3 years & $16 \%$ & $30 \%$ & 0.006 \\
\hline Relapse incidence & $34 \%$ & $29 \%$ & NS \\
\hline DFS at 3 years & $50 \%$ & $42 \%$ & NS \\
\hline OS at 3 years & $65 \%$ & $58 \%$ & NS \\
\hline Moderate/severe cGVHD & $40 \%$ & $27 \%$ & NS \\
\hline
\end{tabular}
relapse-free survival

NS: statistically non-significant; NRM: non-relapse mortality; OS: overall survival; DFS disease-free survival; cGVHD: chronic graft-versus-host disease; EBV: Epstein-Bar virus; CMV: cytomegalovirus; PTCy: posttransplant cyclophosphamide; ATLG: anti Tcell lymphocyte globulin; SD: standard deviation.

\section{Non-relapse mortality}

PTCy was associated with a higher NRM when compared to ATLG on univariate analysis, in addition a positive patient CMV serology, patient age $>52$ years, donor age $>34$ years and female donor were also associated with higher NRM. On multivariate analysis, NRM was not affected by ATLG and PTCy; only donor sex, patient age and CMV serology had a significant impact on NRM (Table3).

\section{Relapse, disease-free survival and overall survival}

After a median follow-up of 16 months (range, 1-169 months) we observed no significant differences in terms of DFS (at 3 years ATLG $51 \%$, PTCy $42 \%, P=0.3$ ), relapse incidence (ATLG $34 \%$ vs. PTCy $29 \%, P=0.261)$, OS ( $65 \%$ vs. $58 \%, P=0.663)$ or moderate/severe cGVHD relapsefree survival at 3 years was (ATLG $40 \%$ vs. PTCy $27 \%$, $P=0.068)$ between the two groups.

\section{Immune reconstitution}

We observed a faster reconstitution of CD3 T lympho- 
cytes $\quad(\mathrm{CD} 3+) \quad(P<0.05)$ and activated $\mathrm{T}$ cells $(\mathrm{CD} 3+/ \mathrm{HLADR}+)$ after ATLG than PTCy $(P<0.05)$ (Figure $1 \mathrm{~A}$ and $\mathrm{B})$. In addition, as shown in Figure 2 and the Online Supplementary Table $S 1$ the reconstitution of cytotoxic $\mathrm{T}$ cells (CD3+/CD8+) and also of naïve cytotoxic $\mathrm{T}$ cells (CD3+/CD8+/CD45RA+) $(P=0.017)$ was significantly faster in the ATLG group (on day $90, P=0.002$ ), while the reconstitution of memory cytotoxic $T$ cells (CD3+/CD8+/CD45R0+) was comparable (Figure 2). In contrast to cytotoxic CD8+ positive cells, CD3 helper cells (CD3+/CD4+) had a trend for faster reconstitution in the PTCy group (Figure 3), which was sustained for naive (CD4+/CD45RA+) $(P=0.002)$ as well as for memory helper cells $(\mathrm{CD} 4+/ \mathrm{CD} 45 \mathrm{R} 0+)(P<0.001)$. The reconstitution of B cells (CD19+) was similar in the ATLG and PTCy group (Figure 4A) and a trend for faster reconstitution of naive B-cells (CD19+/CD27-/CD10+) was observed in the PTCy group (Figure 4B). NK-cell reconstitution was faster on day 30 in the ATLG group $(P<0.001)$, however the values on day 100 and 180 were similar after ATLG and PTCy (Figure 5A). Furthermore, NKT cells and $\gamma \delta \mathrm{T}$ cells reconstitution was faster in the ATLG group $(P<0.05)$ at all time points (Figure $5 \mathrm{~B}$ and $\mathrm{C}$ ), while there were no significant differences in regulatory $\mathrm{T}$-cell immune reconstitution between the two groups.

All our data is summarized in the Online Supplementary Table S1. All our findings were confirmed in a donor subgroup analysis (Online Supplementary Table S2).

\section{Discussion}

Although ATLG and PTCy are widely used for GVHD prevention in allo-SCT, data is scarce on their impact on immune reconstitution and only one small prospective study using RIC PBSC has compared immune reconstitution PTCy to ATLG so far. ${ }^{15}$ In this retrospective study, we compared the influence of ATLG to PTCY on immune reconstitution and transplant outcomes after myeloablative allogeneic PBSC transplant. In our study, we observed some strong differences in terms of cell counts, immune reconstitution, infections moderate/severe cGVHD and EBV reactivation between the two groups.

Since NK and $\gamma \delta \mathrm{T}$ cells have a protective role against many bacterial and viral infections including $\mathrm{CMV}^{16-32}$ the longer period of aplasia and the decreased numbers of NK and NKT cells in the PTCy group can explain the higher incidence of infections before day 100 in this group.

One of the most recent studies of $\gamma \delta \mathrm{T}$-cell recovery and their association with transplant outcomes was conducted on 102 pediatric patients with acute leukemia. ${ }^{33}$ They reported significantly improved PFS and OS in patients with elevated $\gamma \delta T$ cells, these findings have also been reported in adults. ${ }^{34,35}$ In addition they reported a significantly lower incidence of infections with a total absence of bacterial infections in the high $\gamma \delta T$-cell group. ${ }^{33}$ Our findings fall in line with the literature. We observed an early recovery of the $\gamma \delta \mathrm{T}$-cell population in both groups independent of the donor subtype. In addition, $\gamma \delta \mathrm{T}$ cell were consistently higher in the ATLG group in all evaluations when compared to the PTCy group, which may explain the decreased overall incidence of infections in this group. Even though our study was not designed for long term outcomes, we observed no significant difference in DFS or OS between the two groups.
Table 3. Multivariate non-relapse mortality

\begin{tabular}{|c|c|}
\hline Multivariate & $\begin{array}{c}\text { NRM HR (95\% CI) } \\
\text { P-value }\end{array}$ \\
\hline ATLG vs. PTCy & $\begin{array}{c}1.6(0.98-2.48) \\
0.061\end{array}$ \\
\hline $\begin{array}{l}\text { Patient CMV serology } \\
\text { negative } v s \text {. positive }\end{array}$ & $\begin{array}{c}1.73(1.09-2.75) \\
0.02\end{array}$ \\
\hline $\begin{array}{l}\text { Patient age } \\
<52 \text { vs. } \geq 52\end{array}$ & $\begin{array}{c}1.69(1.05-2.73) \\
0.03\end{array}$ \\
\hline $\begin{array}{l}\text { Donor Age } \\
<34 \text { us. } \geq 34\end{array}$ & $\begin{array}{c}1.32(0.81-2.13) \\
0.26\end{array}$ \\
\hline $\begin{array}{l}\text { Donor sex } \\
\text { Male } v \text { s. Female }\end{array}$ & $\begin{array}{c}1.61(1.01-2.59) \\
0.048\end{array}$ \\
\hline $\begin{array}{l}\text { CD34 x106/kg } \\
<7.2 \text { vs. } \geq 7.2\end{array}$ & $\begin{array}{c}0.748(0.46-1.2) \\
0.24\end{array}$ \\
\hline $\begin{array}{l}\text { ECOG } \\
3 \text { vs. } 0-2\end{array}$ & $\begin{array}{c}1.4(0.87-2.14) \\
0.17\end{array}$ \\
\hline
\end{tabular}

NRM: non-relapse mortality; HR: hazard ratio; Cl: confidence interval; ATLG: anti T-cell lymphocyte globulin; PTCy: posttransplant cyclophosphamide; ECOG: Eastern Cooperative Oncology group.

Retiere et al. observed a rapid NK recovery within day 30 after allo-HSCT in the ATLG and PTCy group, however while they reported an increase in NK-cell counts in the ATLG group, they did not observe any effect of the donor type on these values and concluded the recovery rate was a direct effect of the difference in GVHD prophylaxis between the two groups. ${ }^{15}$ Our results fall in line with Retiere's, we observed rapid reconstitution of NK cells at day 30 , and we observed a significantly higher percentage and absolute count of NK cells at day 30 in the ATLG group. This was validated by our donor subgroup analysis which allows us to conclude that this was a direct effect of the difference in the TCD strategy. This supports the hypothesis that ATLG spares NK cells while PTCy targets them. ${ }^{15}$ Rubio et al. reported that early recovery of NKT cells post T-cell-repleted allo-SCT, and a high NKT-cell dose in the graft are associated with protection from aGVHD, ${ }^{36,37}$ In addition Tae et al. report an increase in the incidence of aGVHD and of relapse in patients with lower NKT-cell counts post-allo-SCT. ${ }^{38}$ Retiere et al. did not observe any significant differences in the NKT-cell population between ATLG and PTCy.15 However, in our study, we observed a higher number and percentage of NKT cells in the ATLG group when compared to PTCy and this was confirmed by our subgroup donor analysis. Nonetheless, we did not observe any significant differences in the incidence of relapse or aGVHD, while we observed a significantly lower incidence of moderate and severe cGVHD in the ATLG group when compared to the PTCy group.

Servais et al. studied the impact of ATLG on IR post MAC PBSC allo-SCT. ${ }^{39}$ They looked precisely at memory and naive T cells and they observed that ATLG selectively depletes naïve $\mathrm{CD} 4+\mathrm{T}$ and naïve $\mathrm{CD} 8+\mathrm{T}$ cells whereas it does not significantly impact memory Tcells. ${ }^{39}$ Our results fall in line with Servais et al., as we observed a progressive increase in the naïve to memory ratio both in the $\mathrm{CD} 4+\mathrm{T}$ cells and $\mathrm{CD} 8+\mathrm{T}$ cells, indicating that the effect of ATLG effect is more pronounced on naïve $T$ cells than on memory $\mathrm{T}$ cells. However, in our study the effect of ATLG on naive and memory CD4+ T cells was 
A

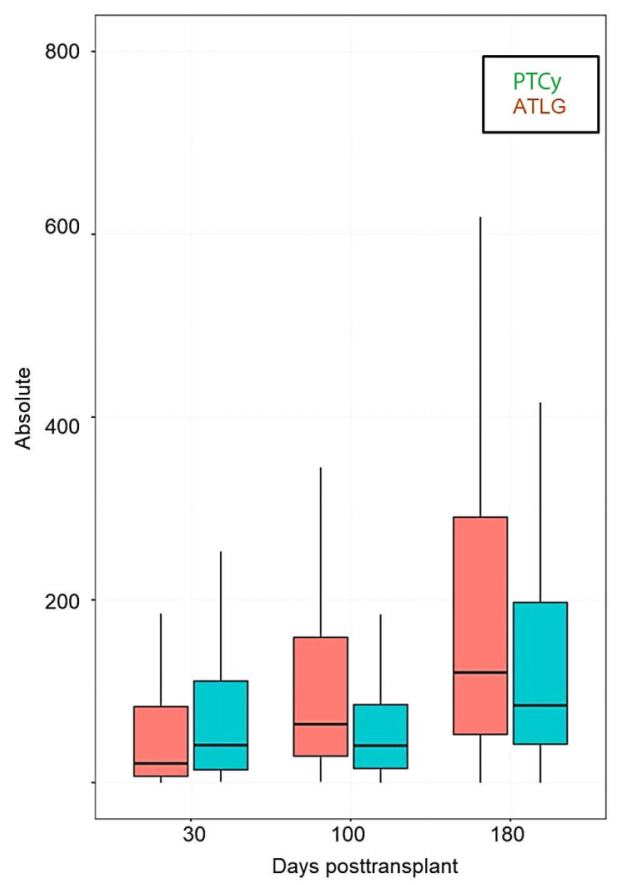

Activated T lymphocytes

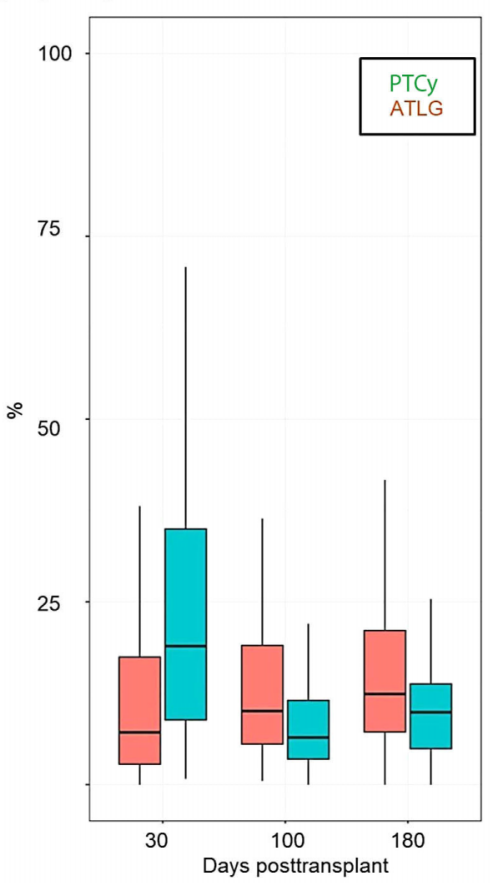

Figure 1. Comparison between ATLG and PTCy regarding immune reconstitution of (A) activated $T$ cells $\mathrm{CD} 3+/ \mathrm{HLADR}+)$ and (B) all T cells $(\mathrm{CD} 3+) \quad P^{*}=P$-value at day $30 ; P^{* *}=P$-value at day 100; $P^{* * *}=P$-value at day $180 ; \%$ : percentage of cells; Absolut: absolute number of cells. TLG: anti Tcell lymphocyte globulin; PTCy: and post-transplant cyclophosphamide.

\section{T lymphocytes}

\section{B}

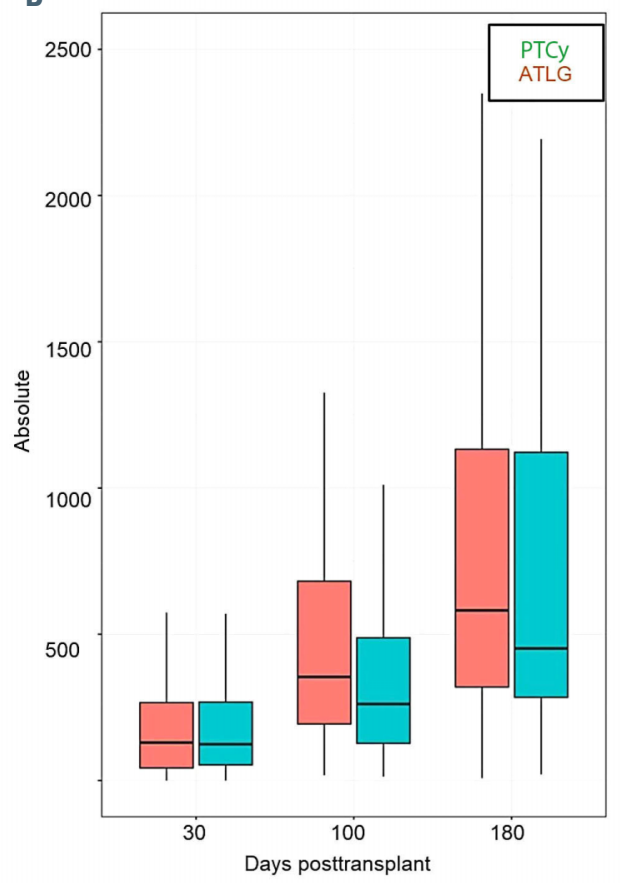

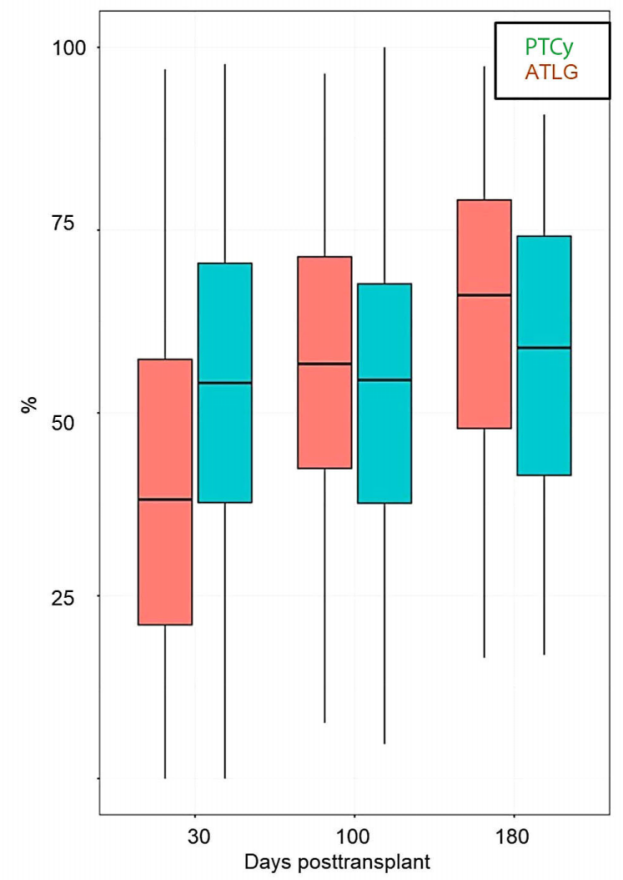

more pronounced than PTCy. In our study the reconstitution of CD8+ T cells was faster than that of CD4+ Tcells with CD8+ T cells recovering by day 100 , while the CD4+ T-cell reconstitution was not observed at the last evaluation of the immune profile on day 180 . In addition, the $\mathrm{CD} 4+/ \mathrm{CD} 8+$ ratio did not return to normal in either of the two groups, which indicates incomplete recovery of the CD4+ T-cell compartment. These findings were confirmed by subgroup analysis according to the donor.

It is well established that reconstitution of the T-cell compartment after allo-HSCT arises from both homeo- static peripheral expansion (HPE) of donor T cells transferred with the graft and from the novel production of naïve $\mathrm{T}$ cells in the thymus. ${ }^{40,41}$ In patients receiving MAC most of the T cells originate from HPE, and given that ATLG persist for several weeks in circulation, ${ }^{42,43}$ it can be hypothesized that ATLG selectively depletes donor naive $T$ cells while it spares other T-cell populations. This differential cytotoxic activity of ATLG has been demonstrated in vitro. ${ }^{44}$ In addition, HPE occurs more asymmetrically between $\mathrm{T}$ cells, with CD8+ T cells having higher proliferating potential by HPE when compared to $\mathrm{CD} 4+\mathrm{T}$ cells. ${ }^{39}$ This may explain the decreased 
A

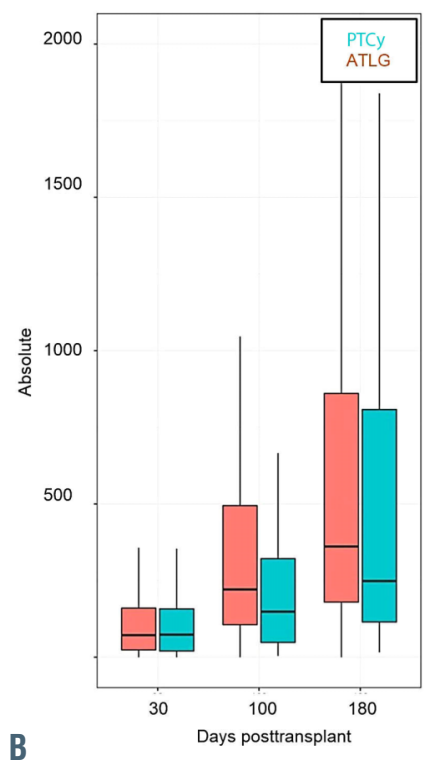

Total CD8+ T cells

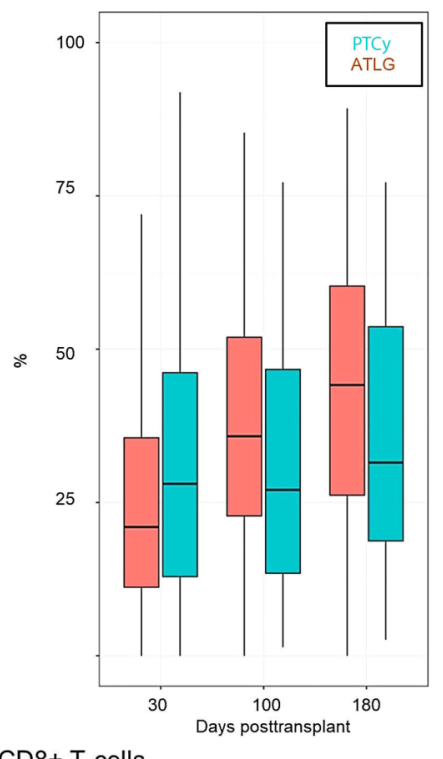

Figure 2. Comparison between ATLG and PTCY regarding immune reconstitution of CD8+ cells. (A) Total CD8+ T cells; (B) naïve CD8+ T cells; (C) memory CD8+ T cells. $P^{*}=P$ value at day $30 ; P^{* *}=P$-value at day 100 ; $P * * *=P$-value at day 180; \%: percentage of cells; Absolut: absolute number of cells. ATLG: anti T-cell lymphocyte globulin; PTCy: and post-transplant cyclophosphamide.
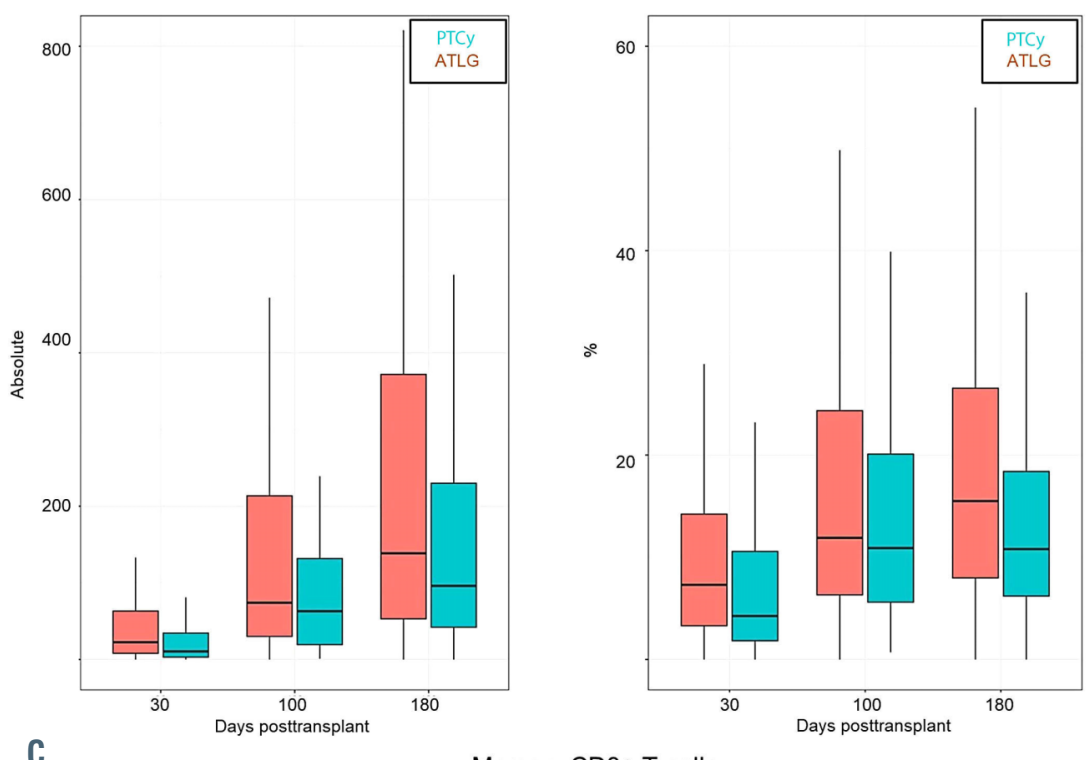

Memory CD8+ T cells
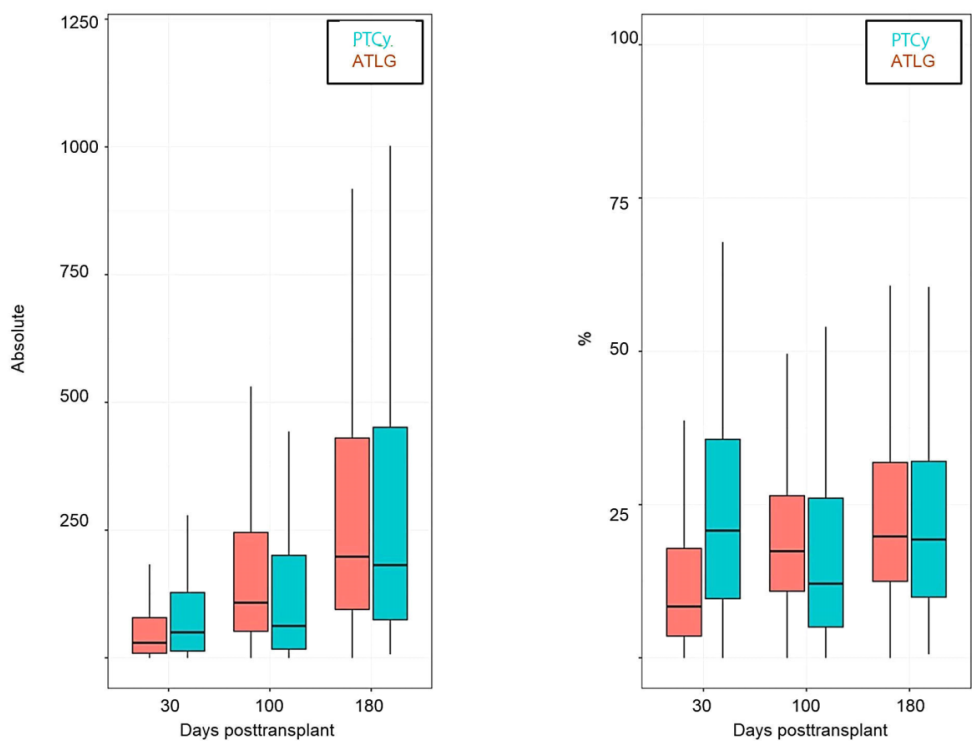
A

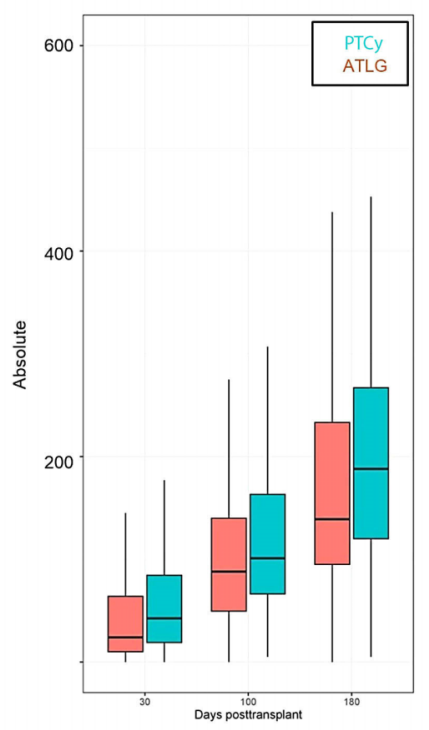

B

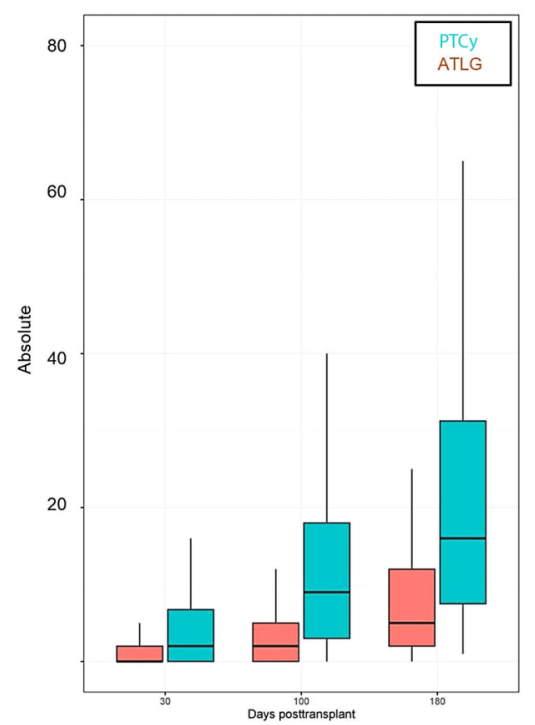

Total CD4+ T cells

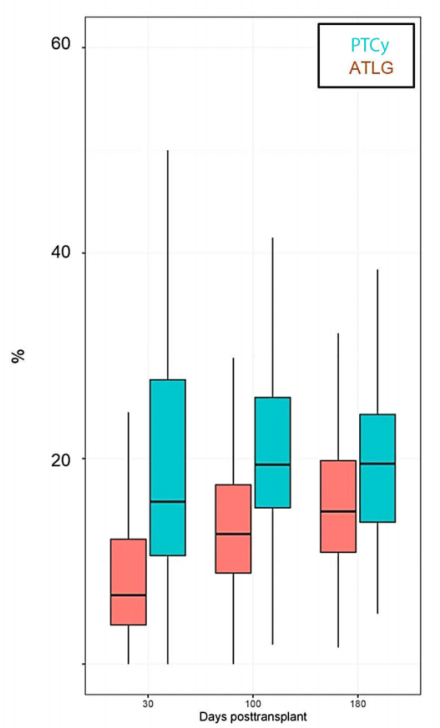

Naïve CD4+ T cells

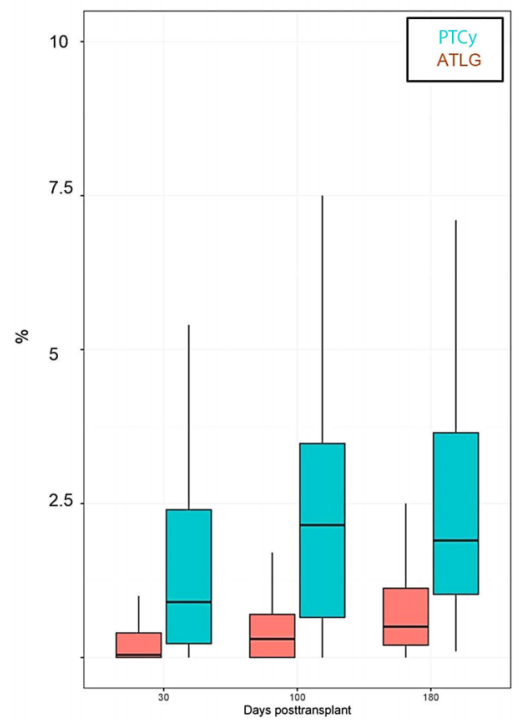

Figure 3. Immune reconstitution for CD4+ Tcell ATLG versus PTCy. (A) Total CD4+ T cells; (B) naïve CD4+ T cells; (C) memory CD4+ T cells. $P^{*}=P$-value at day $30 ; P^{* *}=P$-value at day $100 ; P^{* * *}=P$-value at day $180 ; \%$ : percentage of cells; Absolut: absolute number of cells. ATLG: anti T-cell lymphocyte globulin; PTCy: and post-transplant cyclophosphamide.

C

Memory CD4+ T cells
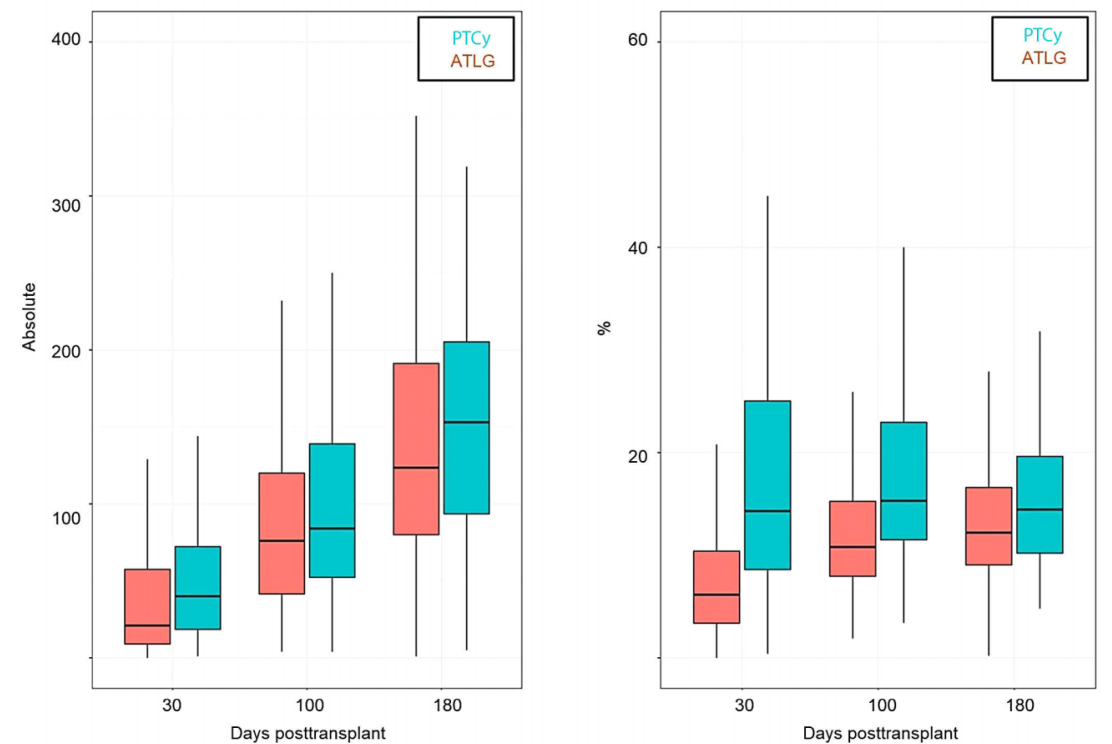
A

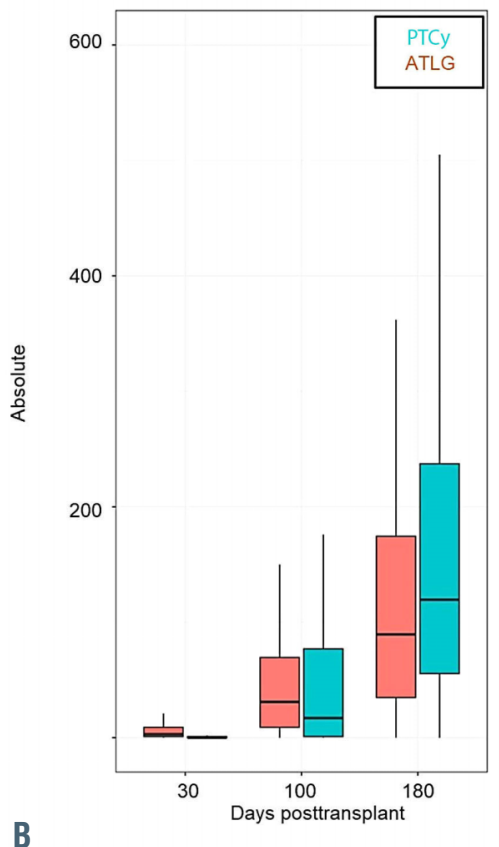

B

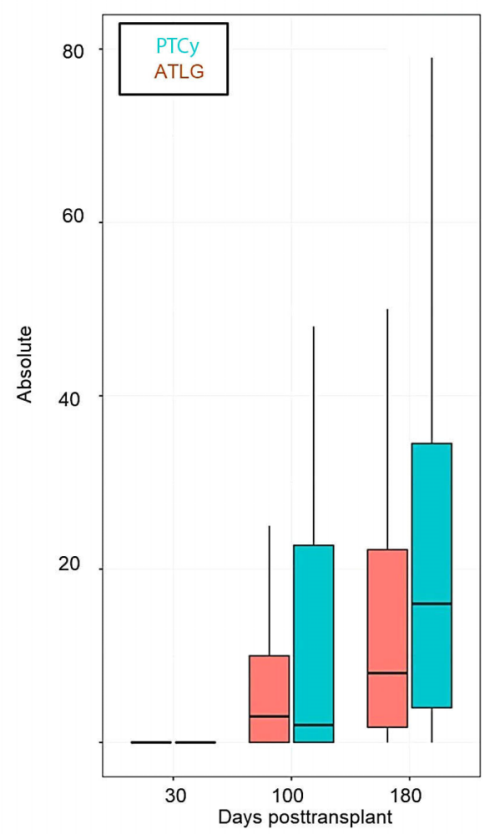

Total B lymphocytes

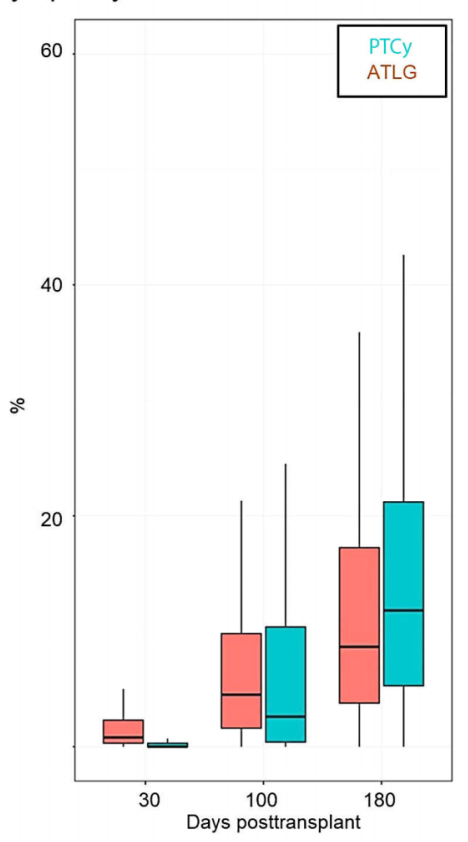

Naïve B cells

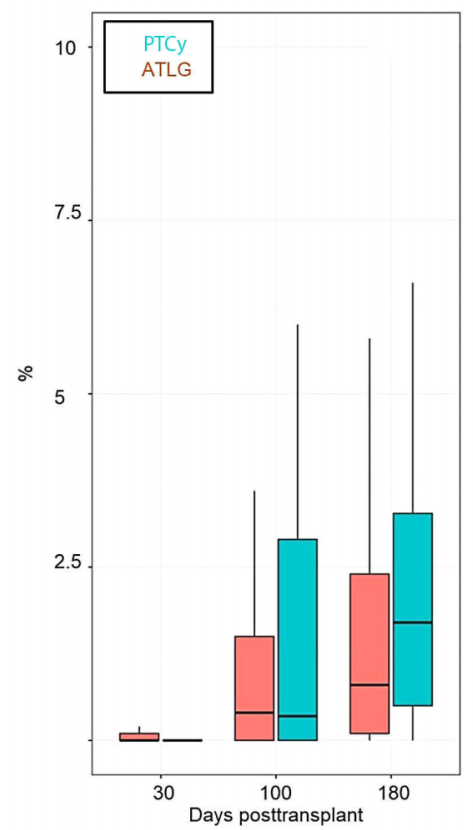

Figure 4. Comparison between ATLG and PTCy regarding immune reconstitution of $B$ cells(A) Total B cells; (B) naïve B cells. $P^{*}=P$ value at day $30 ; P^{* *}=P$-value at day 100 ; $P * * *=P$-value at day 180; \%: percentage of cells; Absolut: absolute number of cells. ATLG: anti T-cell lymphocyte globulin; PTCy: and post-transplant cyclophosphamide.
CD4+ T-cell population and increased CD8+ T-cell numbers in the ATLG group. Another explanation for the decreased number of CD8+ T cells in the PTCy group is the ability of PTCy to selectively target proliferating NK and CD8+ T cells more than CD4+ T cells. ${ }^{15}$ These findings were all validated in the donor subgroup analyses which makes it safe to assume that the observed discrepancies between the ATLG and PTCy groups can be attributed to the difference in the TCD between the groups. From our findings, we can hypothesize that PTCy has less impact on all the CD4+ T cells, while it has increased activity against $C D 8+T$ cells, which was expressed by higher proliferation of CD4+ T cells in the PTCy and CD8+ T cells in the ATLG group. In addition, we can hypothesize that ATLG has a more pronounced effect on memory CD8+ and CD4+ T cells than PTCy.
The higher percentage of $\mathrm{T}$ lymphocytes and activated lymphocytes in the ATLG group may be explained by the higher CD8+ T-cell and NTK-cell reconstitution observed in this group.

It has been proven in animal models that Tregs suppress GVHD without decreasing GVL, ${ }^{45}$ and that they accelerate post-transplant T-cell immune reconstitution in murine models. ${ }^{46}$ In our study Tregs persisted after transplant and we observed no significant differences in Treg reconstitution post-allo-HSCT between the two groups. This may be explained by the cyclophosphamide resistance of Tregs conferred by their increase in the expression of aldehyde dehydrogenase for cyclophosphamide detoxification which allow them to persist posttransplant in the PTCy setting, ${ }^{10,15}$ and by the selective sparing of Tregs by ATLG. ${ }^{39}$

After allo-HSCT the numbers of total B cells normalize 
A

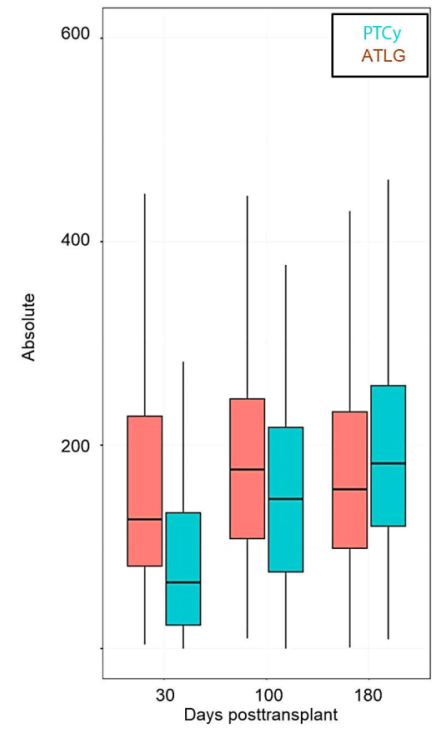

B

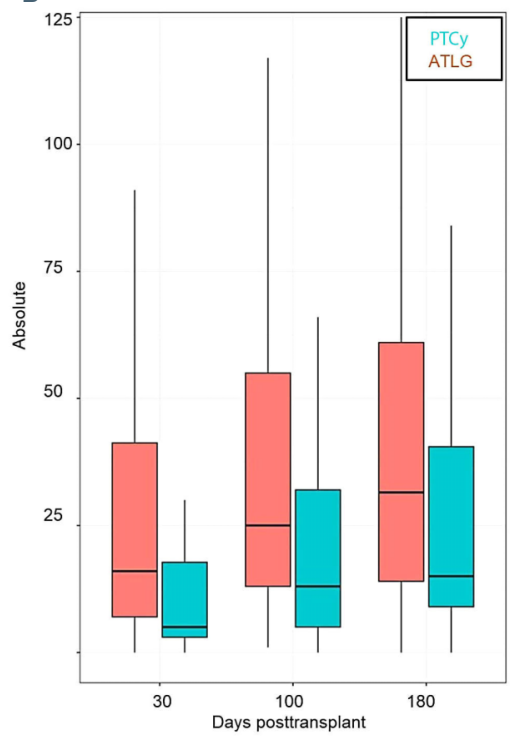

C

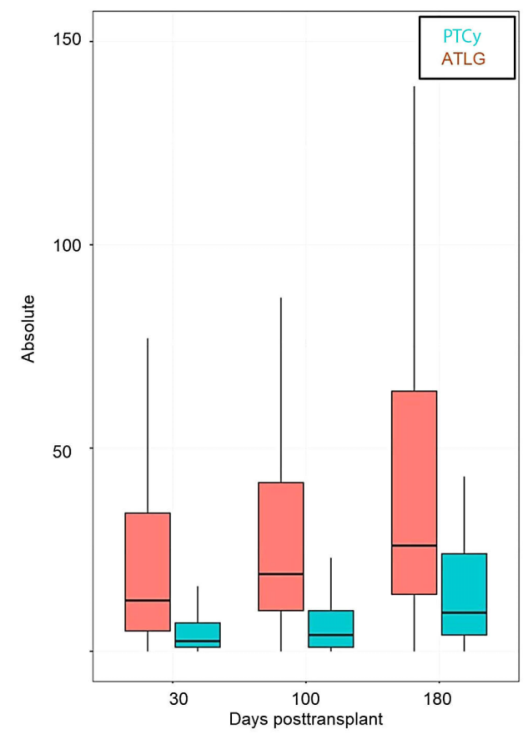

NK cells

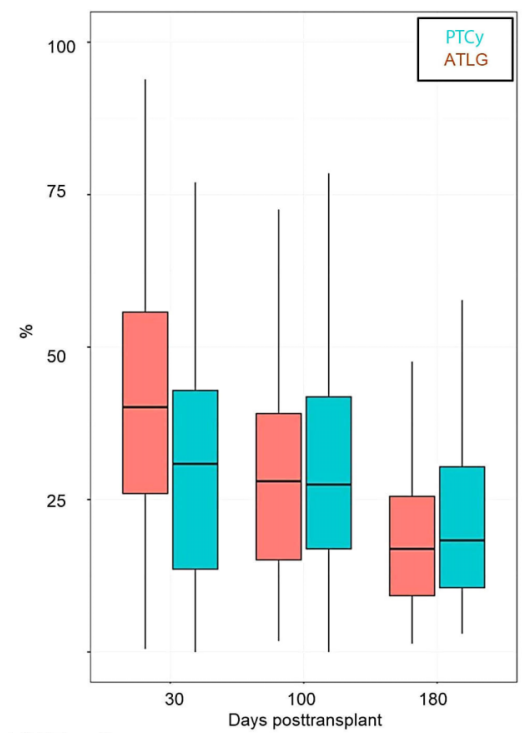

NK T cells

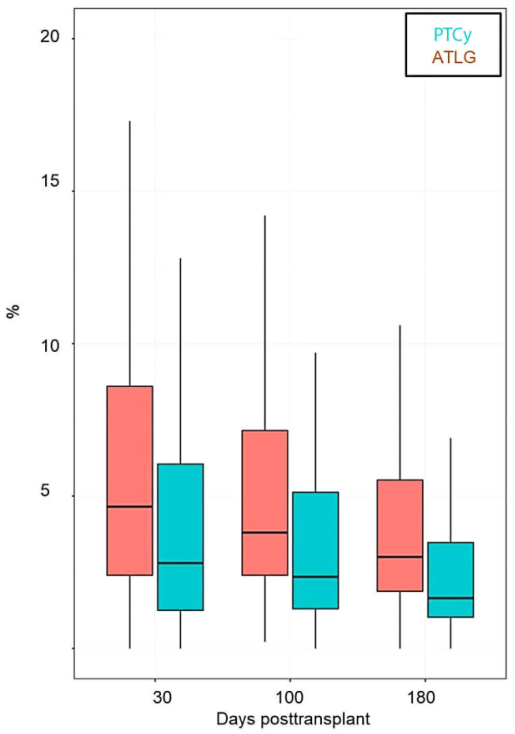

$\gamma \delta$ T cells

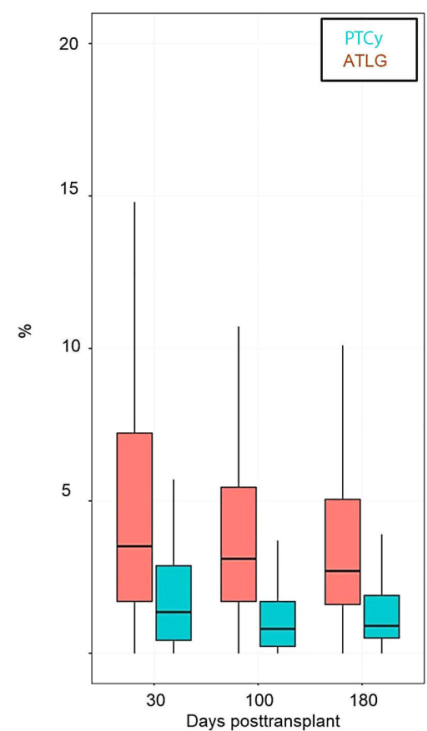

Figure 5. Comparison between ATLG and PTCy regarding immune reconstitution of innate immune system (A) B natural killer (NK) cells; (B) natural killer T (NKT) cells; (C) $\gamma \delta$ T cells. $P^{*}=P$-value at day $30 ; P^{* *}=P$-value at day 100; $P * * *=P$-value at day $180 ; \%$ : percentage of cells; Absolut: absolute number of cells. ATLG: anti T-cell lymphocyte globulin; PTCy: and post-transplant cyclophosphamide. 
within 3 months to 1 year. ${ }^{47-49}$ However, the reconstitution in the first year compromise mainly transitional and naïve subsets and memory B cells occurs much later. Our results show normalization of the total B-lymphocyte count at day 60 , but no complete recovery of naïve and memory Bcells at last follow-up. In addition, we observed a higher percentage and count of naive B cells in the PTCy group at day 100.

Even though we observed a higher incidence of NRM in the PTCY group on univariate analysis, this did not persist on multivariate analysis (hazard ratio 1.6; 95\% Confidence Interval: $0.98-2.48 ; P=0.061)$. This difference can be explained by a higher proportion of high risk patients (higher proportion of mismatch transplants and ALL) in the PTCY group when compared to ATLG.

Given the retrospective nature of our study and the heterogeneity of our patient population especially the differences in donor types, ATLG dosing, immune suppression regiments and conditioning regimens, it should be noted that our study is prone to bias especially with univariate analysis. In an attempt to reduce bias and render the population more homogenous we selected consecutive patients undergoing allo-SCT only with MAC regimens and PBSC as a stem cell source. In addition, we conducted subgroup analysis in which we found anecdotal differences in clinical outcomes and IR between the $30 \mathrm{mg} / \mathrm{kg}$ and $60 \mathrm{mg} / \mathrm{kg}$ ATLG dose, and we confirmed our findings in a subgroup analysis according to donor type. However, our findings should be confirmed in more homogenous prospective studies.

\section{Conclusion}

Acknowledging the bias associated with our study especially its retrospective nature, while taking into consideration the large sample size, it is safe to conclude that a better CD8+ T-cell, NK-cell, NKT-cell and $\gamma \delta$ T-cell reconstitution is observed in the ATLG group while improved CD4+ recovery is a hallmark of the PTCy group. Even though these findings have been translated into a decreased incidence of infection and moderate/severe cGVHD in the ATLG group they had no impact on any of the other long-term outcomes. So, it remains undetermined which TCD strategy is better to consider and results from well-designed randomized studies are needed.

\section{Disclosures}

No conflicts of interest to disclose.

\section{Contributions}

$R M$ and NK designed the study, analyzed data, interpreted results, and wrote the manuscript; NG, UFF, GZ, SH, CW, FA, and $M C$ collected and analyzed data. All authors approved the final version of the manuscript.

\section{References}

1. Copelan EA. Hematopoietic stem-cell transplantation. N Engl J Med. 2006;354 (17):1813-1826.

2. Horowitz MM, Gale RP, Sondel PM, et al. Graft-versus-leukemia reactions after bone marrow transplantation. Blood. 1990;75(3): 555-562.

3. Glucksberg H, Storb R, Fefer A, et al. Clinical manifestations of graft-versus-host disease in human recipients of marrow from HL-A-matched sibling donors. Transplantation. 1974;18(4):295-304.

4. Chang YJ, Zhao XY, Huang XJ. Immune reconstitution after haploidentical hematopoietic stem cell transplantation. Biol Blood Marrow Transplant. 2014;20 (4):440-449.

5. Roberto A, Castagna L, Zanon V, et al. Role of naive-derived T memory stem cells in Tcell reconstitution following allogeneic transplantation. Blood. 2015;125(18):28552864.

6. Kanakry CG, O'Donnell PV, Furlong T, et al. Multi-institutional study of post-transplantation cyclophosphamide as singleagent graft-versus-host disease prophylaxis after allogeneic bone marrow transplantation using myeloablative busulfan and fludarabine conditioning. J Clin Oncol. 2014;32(31):3497-3505.

7. Kanakry CG, Tsai HL, Bolanos-Meade J, et al. Single-agent GVHD prophylaxis with posttransplantation cyclophosphamide after myeloablative, HLA-matched BMT for AML, ALL, and MDS. Blood. 2014;124 (25):3817-3827.

8. Jacoby E, Chen A, Loeb DM, et al. Singleagent post-transplantation cyclophosphamide as graft-versus-host disease prophylaxis after human leukocyte antigenmatched related bone marrow transplanta- tion for pediatric and young adult patients with hematologic malignancies. Biol Blood Marrow Transplant. 2016;22(1):112-118.

9. Wachsmuth LP, Patterson MT, Eckhaus MA, Venzon DJ, Gress RE, Kanakry CG. Post-transplantation cyclophosphamide prevents graft-versus-host disease by inducing alloreactive $T$ cell dysfunction and suppression. J Clin Invest. 2019;129(6): 2357-2373

10. Kanakry CG, Coffey DG, Towlerton AM, et al. Origin and evolution of the $T$ cell repertoire after posttransplantation cyclophosphamide. JCI Insight. 2016;1(5): e86252.

11. Rubio MT, Labopin M, Blaise D, et al. The impact of graft-versus-host disease prophylaxis in reduced-intensity conditioning allogeneic stem cell transplant in acute myeloid leukemia: a study from the Acute Leukemia Working Party of the European Group for Blood and Marrow Transplantation. Haematologica. 2015;100 (5):683-689.

12. Bacigalupo A, Ballen K, Rizzo D, et al. Defining the intensity of conditioning regimens: working definitions. Biol Blood Marrow Transplant. 2009;15(12):16281633.

13. Przepiorka D, Weisdorf D, Martin P, et al. 1994 Consensus Conference on Acute GVHD Grading. Bone Marrow Transplant. 1995;15(6):825-828.

14. Filipovich AH, Weisdorf D, Pavletic S, et al. National Institutes of Health consensus development project on criteria for clinical trials in chronic graft-versus-host disease: I. Diagnosis and staging working group report. Biol Blood Marrow Transplant. 2005;11(12):945-956.

15. Retiere C, Willem C, Guillaume T, et al. Impact on early outcomes and immune reconstitution of high-dose post-transplant cyclophosphamide vs anti-thymocyte glob- ulin after reduced intensity conditioning peripheral blood stem cell allogeneic transplantation. Oncotarget. 2018;9(14):1145111464.

16. Horowitz A, Stegmann KA, Riley EM Activation of natural killer cells during microbial infections. Front Immunol. 2011:2:88.

17. Adib-Conquy M, Scott-Algara D, Cavaillon JM, Souza-Fonseca-Guimaraes F. TLRmediated activation of NK cells and their role in bacterial/viral immune responses in mammals. Immunol Cell Biol. 2014;92(3): 256-262.

18. Lunemann S, Malone DF, Hengst J, et al. Compromised function of natural killer cells in acute and chronic viral hepatitis. J Infect Dis. 2014;209(9):1362-1373.

19. Hall LJ, Murphy CT, Hurley G, et al. Natural killer cells protect against mucosal and systemic infection with the enteric pathogen Citrobacter rodentium. Infect Immun. 2013;81(2):460-469.

20. Han X, Fan Y, Wang S, Jiao L, Qiu H, Yang $X$. NK cells contribute to intracellular bacterial infection-mediated inhibition of allergic responses. J Immunol. 2008;180(7):46214628.

21. Nogusa S, Ritz BW, Kassim SH, Jennings SR, Gardner EM. Characterization of agerelated changes in natural killer cells during primary influenza infection in mice. Mech Ageing Dev. 2008;129(4):223-230.

22. Alter G, Martin MP, Teigen N, et al. Differential natural killer cell-mediated inhibition of HIV-1 replication based on distinct KIR/HLA subtypes. J Exp Med. 2007;204(12):3027-3036.

23. Harshan KV, Gangadharam PR. In vivo depletion of natural killer cell activity leads to enhanced multiplication of Mycobacterium avium complex in mice. Infect Immun. 1991;59(8):2818-2821.

24. Katz P, Yeager H, Jr., Whalen G, Evans M, 
Swartz RP, Roecklein J. Natural killer cellmediated lysis of Mycobacterium-avium complex-infected monocytes. J Clin Immunol. 1990;10(1):71-77.

25. Blanchard DK, Stewart WE 2nd, Klein TW, Friedman H, Djeu JY. Cytolytic activity of human peripheral blood leukocytes against Legionella pneumophila-infected monocytes: characterization of the effector cell and augmentation by interleukin 2. J Immunol. 1987;139(2):551-556.

26. Klimpel GR, Niesel DW, Klimpel KD. Natural cytotoxic effector cell activity against Shigella flexneri-infected HeLa cells. J Immunol. 1986;136(3):1081-1086.

27. Vantourout P, Hayday A. Six-of-the-best: unique contributions of $\gamma \delta \mathrm{T}$ cells to immunology. Nat Rev Immunol. 2013;13 (2):88-100.

28. Kalyan S, Kabelitz D. Defining the nature of human $\gamma \delta \mathrm{T}$ cells: a biographical sketch of the highly empathetic. Cell Mol Immunol. 2013;10(1):21-29.

29. Zheng J, Liu Y, Lau Y-L, Tu W. $\gamma \delta$-T cells: an unpolished sword in human anti-infection immunity. Cell Mol Immunol. 2013;10(1): 50-57.

30. Scheper W, van Dorp S, Kersting S, et al. $\gamma \delta \mathrm{T}$ cells elicited by CMV reactivation after allo-SCT cross-recognize CMV and leukemia. Leukemia. 2013;27(6):1328-1338.

31. Knight A, Madrigal AJ, Grace S, et al. The role of V82-negative $\gamma \delta \mathrm{T}$ cells during cytomegalovirus reactivation in recipients of allogeneic stem cell transplantation. Blood. 2010;116(12):2164-2172.

32. Elmaagacli AH, Steckel NK, Koldehoff M, et al. Early human cytomegalovirus replication after transplantation is associated with a decreased relapse risk: evidence for a putative virus-versus-leukemia effect in acute myeloid leukemia patients. Blood. 2011;118(5):1402-1412.

33. Perko R, Kang G, Sunkara A, Leung W, Thomas PG, Dallas MH. Gamma delta T cell reconstitution is associated with fewer infections and improved event-free survival after hematopoietic stem cell transplantation for pediatric leukemia. Biol Blood Marrow Transplant. 2015;21(1):130-136.

34. Lamb Jr L, Gee AP, Hazlett LJ, et al. Influence of $\mathrm{T}$ cell depletion method on circulating $\gamma \delta \mathrm{T}$ cell reconstitution and potential role in the graft-versus-leukemia effect. Cytotherapy. 1999;1(1):7-19.

35. Godder K, Henslee-Downey P, Mehta J, et al. Long term disease-free survival in acute leukemia patients recovering with increased $\gamma \delta \mathrm{T}$ cells after partially mis matched related donor bone marrow trans plantation. Bone Marrow Transplant. 2007;39(12):751-757.

36. Salio M, Silk JD, Yvonne Jones E, Cerundolo V. Biology of CD1-and MR1restricted T cells. Annu Rev immunol. 2014;32:323-366.

37. Bendelac A, Savage PB, Teyton L. The biology of NKT cells. Annu Rev Immunol. 2007;25:297-336.

38. Kim TW, Park S-S, Lim J-Y, et al. Predictive role of circulating immune cell subtypes early after allogeneic hematopoietic stem cell transplantation in patients with acute leukemia. Int J Stem Cell 2019;12(1):73-83.

39. Servais S, Menten-Dedoyart C, Beguin Y, et al. Impact of pre-transplant anti-T cell globulin (ATG) on immune recovery after myeloablative allogeneic peripheral blood stem cell transplantation. PLoS One. 2015;10(6): e0130026.

40. Bosch M, Dhadda M, Hoegh-Petersen M, et al. Immune reconstitution after anti-thymocyte globulin-conditioned hematopoietic cell transplantation. Cytotherapy. 2012;14(10):1258-1275.

41. Toubert A, Glauzy S, Douay C, Clave E. Thymus and immune reconstitution after allogeneic hematopoietic stem cell transplantation in humans: never say never again. Tissue Antigens. 2012;79(2):83-89.
42. Chawla S, Dharmani-Khan P, Liu Y, et al. High serum level of antithymocyte globulin immediately before graft infusion is associated with a low likelihood of chronic, but not acute, graft-versus-host disease. Biol Blood Marrow Transplant. 2014;20(8): 1156-1162.

43. Remberger M, Sundberg B. Rabbitimmunoglobulin $\mathrm{G}$ levels in patients receiving thymoglobulin as part of conditioning before unrelated donor stem cell transplantation. Haematologica. 2005;90(7):931-938.

44. Pearl JP, Parris J, Hale DA, et al. Immunocompetent T-cells with a memorylike phenotype are the dominant cell type following antibody-mediated T-cell depletion. Am J Transplant. 2005;5(3):465-474

45. Edinger $M$, Hoffmann $P$, Ermann J, et al CD4+ CD25+ regulatory $\mathrm{T}$ cells preserve graft-versus-tumor activity while inhibiting graft-versus-host disease after bone marrow transplantation. Nat Med. 2003;9(9): 1144-1150.

46. Nguyen VH, Shashidhar S, Chang DS, et al The impact of regulatory $\mathrm{T}$ cells on $\mathrm{T}$-cell immunity following hematopoietic cell transplantation. Blood. 2008;111(2):945953.

47. Storek J, Ferrara S, Ku N, Giorgi JV, Champlin RE, Saxon A. B cell reconstitution after human bone marrow transplantation: recapitulation of ontogeny? Bone Marrow Transplant. 1993;12(4):387-398.

48. Storek J, Dawson MA, Storer B, et al. Immune reconstitution after allogeneic marrow transplantation compared with blood stem cell transplantation. Blood. 2001;97(11):3380-3389.

49. Small TN, Keever CA, Weiner-Fedus S Heller G, O'Reilly RJ, Flomenberg N. B-cell differentiation following autologous, conventional, or T-cell depleted bone marrow transplantation: a recapitulation of norma B-cell ontogeny. Blood. 1990;76(8):16471656. 